International Journal of Environment, Agriculture and Biotechnology
Vol-6, Issue-6; Nov-Dec, 2021
JJEAB
Journal Home Page Available: https://ijeab.com/
Journal DOI: $10.22161 /$ ijeab

\title{
Response of Cabbage (Brassica oleracea var capitata) to Organic and Inorganic Fertilizers on Growth and Yield Parameters and Incidence of Insect Pest
}

\author{
S. Iddrisu ${ }^{1 *}$, M. E. Essilfie ${ }^{2}$, G. Bolfrey - Arku $^{3}$
}

\begin{abstract}
${ }^{1}$ Department of Science, Atebubu College of Education .P.O.Box 29, Atebubu, Ghana. Email: iddrisusumaila13@gmail.com ${ }^{2}$ Department of Crop and Soil Sciences Education, Faculty of Agriculture Education, P.O.Box 40, Akenten Appiah-Menka University of Skills Training and Entrepreneurial Development (AAMUSTED) Mampong-Ashanti, Ghana. Email: maggifremp@yahoo.co.uk, ${ }^{3}$ Plant Health Dvision, CSIR- Crops Research Institute, Fumesua, Kumasi, Ghana._Email: gbarku4@gmail.com, gbarku4@yahoo.co.uk *Corresponding Author
\end{abstract}

Received: 07 Oct 2021; Received in revised form: 25 Nov 2021; Accepted: 05 Dec 2021; Available online: 12 Dec 2021 (C)2021 The Author(s). Published by Infogain Publication. This is an open access article under the CC BY license (https://creativecommons.org/licenses/by/4.0/).

\begin{abstract}
Two field experiments were conducted for two cropping seasons at the Multipurpose Crop Nursery of the Akenten Appiah-Menka University of Skills Training and Entrepreneurial Development Mampong-Ashanti, from August to November, 2015and June to September, 2016 to determine the response of cabbage (Brassica oleracea var capitata) to organic and inorganic fertilizers on growth, yield and incidence of insect pest. The experimental design used for the field experiment was a randomized complete block design (RCBD) with three replications. The treatments were: poultry manure $\left(20 \mathrm{t} \mathrm{ha^{-1 }}\right)+$ Cypermetrine $\left(30 \mathrm{l} \mathrm{ha^{-1 }}\right)$, cow dung $\left(20\right.$ t ha $\left.a^{-1}\right)+$ Cypermetrine $\left(30 \mathrm{l} \mathrm{ha}^{-1}\right)$, N.P.K (15:15:15) $(300 \mathrm{~kg})+$ Cypermetrine $\left(30 \mathrm{lha}^{-1}\right)$, foliar + Cypermetrine (30 l ha $\left.{ }^{1}\right)$, poultry manure $\left(20 \mathrm{tha^{-1 }}\right)+$ neem leaf extract, cow dung $\left(20 \mathrm{t} \mathrm{ha}^{-1}\right)+$ neem leaf extract, N.P.K $(15: 15: 15)(300 \mathrm{~kg})+$ neem leaf extract, foliar + neem leaf extract and the control (no fertilizer and no insecticide). The result revealed that the application of organic manure (poultry manure and cow dung) and inorganic fertilization is a better option for soil fertility enhancement in cabbage production. High percentage crop establishment (>95\%) was achieved across treatments with NPK + Cypermetrine, poultry manure + neem, N.P.K (15:15:15) + Neem or Foliar fertilizer + neem achieving 100\% crop establishment. The application of Cow dung + NLE produced the highest number of open leaves in both seasons. Application of poultry manure and N.P.K combined with Cypermetrine significantly improved head weight and cabbage yield.Application of poultry manure combined with Cypermetrine or neem leaf extract produced earliest head initiation and widest head diameter.In conclusion cabbage growers are encouraged to use poultry manure at 20 t ha $a^{-1}$ and N.P.K (15:15:15) (300 kg) combined with Cypermetrine at $30 \mathrm{l} \mathrm{ha}^{-1}$ and neem leaf extract for the improvement of cabbage growth, yield and incidence of insect pest.
\end{abstract}

Keywords - foliar, cabbage, poultry manure, cow dung, cypermetrine, neem leaf extract.

\section{INTRODUCTION}

Cabbage demand is high on the Ghanaian domestic market, serving as a source of vitamin and mineral requirements as well as a major source of income to the youth and women in urban and peri-urban areas (Timbilla and Nyarko, 2004). The crop is high in water content, fibre, protein, calcium, iron, and vitamins $\mathrm{A}$ and $\mathrm{C}$ (Adeniji et al., 2010; Meena et al., 2010). The rise in the consumption of cabbage has necessitated the increase production of the crop in Ghana. However, the productivity of cabbage per unit area is rather low compared to other developed countries of the world. This is as a result of numerous production challenges faced by farmers. Notable among them are soil nutrient and pest management which are required for better growth and yield of cabbage. Nutrient supply is an important input for realizing higher cabbage yield and its nutrient content 
(Hasan et al., 2018). There is high cost of inorganic fertilizers (Snr et al., 2018). This makes it difficult for the local farmer to boost production and to increase yield, thereby reducing yield and their income levels. The habit of applying synthetic insecticides to control cabbage pest has been the traditional practice among most farmers in Ghana. The heightening consciousness of the danger associated with the use of synthetic insecticides as well as their high costs of control has necessitated for a less dangerous form of pest control. Organic pesticides have long been an alternative to synthetic chemical insecticides for pest control and management. This is because they pose little threat to the environment and to human health (Appiahet al., 2014).

Cabbage has high requirements for all nutrients, especially nitrogen and it demands for achieving high yields range from 130-310 kg/ha (Milas and Vincent, 2017). Nitrogen over-use in modern agriculture is of importance with respect to both environmental concerns and the quality of plant products. Cow dung is a potential source of nutrients and also a potential benefit to soil amelioration, especially for communal farmers who cannot afford fertilizers. However, getting maximum value out of the manure requires applying it at proper rates and frequency in conjunction to a particular soil (Pahlaret al., 2013).

The suitability and usefulness of cow dung has been attributed to high availability of N.P.K content and increased availability of organic matter content to degraded soil which may lead to the increasing activity of beneficial microorganisms and improves the physical properties of the soil (Snr et al., 2020). The plant has good responsiveness on animal manure application in quantity of $40 \mathrm{t} / \mathrm{ha}$. Organic manuring enhances soil biological activity, improves nutrient mobilization, soil structure and increases soil water retention (Roy and Kashem, 2014). Crop production with integrated use of mineral and organic manure has proved to be highly beneficial by increasing yield as well as keep the environment sound. In the past, agricultural production was focused on maximizing the quantity of vegetables produced for commercial markets (Pavla and Pokluda, 2008); while in the last few decades the organic management of crops has gained popularity because of increased consumer's awareness of the health problems that come from food grown under conventional farming. Differences between organic manure and inorganic fertilizers, especially in soil fertility management may affect the nutritive composition of plants (Hassan and Solaiman, 2012). Shapla (2013) reported that manure applied in correct proportion, does not just improve soil porosity but it also contributes to good plant growth, development and yield, chlorophyll and N.P.K content.
In view of the benefits to the diet and the livelihood of the Ghanaian populace and to determine the effectiveness of fertilizers for soil improvement and maintenance on cabbage, it is of much importance to find out the response of cabbage (Brassica oleracea var capitata) to organic and inorganic fertilizers on growth and yield parameters and incidence of insect pest.

\section{MATERIALS AND METHODS}

\subsection{Description of study area}

Two field experiments were conducted on two different plots at the Multipurpose Crop Nursery at the Akenten Appiah-Menka University of Skills Training and Entrepreneurial Development (AAM- USTED) MampongAshanti from August to November, 2015 and June to September, 2016. Mampong-Ashanti is located within the transitional agro-ecological zone of Ghana, lying between the semi deciduous forest to the south and the Guinea savannah region to the north. It is located at latitude $07^{0}$ and $08^{\circ}$ north of the Equator and longitude $01^{\circ}$ and $24^{\circ}$ west. It is $457.5 \mathrm{~m}$ above sea level.

The climatic conditions at the experimental sites were determined during 2015 and 2016 cropping seasons. The climatic conditions during the field research periods show that differences in environmental factors (rainfall, temperature and relative humidity) were shown in both cropping seasons. The total monthly rainfall for 2015 cropping season was $287.5 \mathrm{~mm}$ and it occurred from August to November, 2015 with the peak in September and October (Ghana Meteorological Agency - Mampong Ashanti, 2015). The mean monthly temperature for the area for the 2015 cropping season ranged between $22.8^{\circ} \mathrm{C}$ to $30.8{ }^{\circ} \mathrm{C}$ with the highest daily temperature of $32.6^{\circ} \mathrm{C}$ occurring in November, 2015.The mean monthly relative humidity ranged from 60.3 to $92.2 \%$ with the peak occurring between September and November.

In the 2016 cropping season, for experiment two (2), the total monthly rainfall was $647.8 \mathrm{~mm}$ and it occurred from June to September, with the peak in June, July and September (Ghana Meteorological Agency - Mampong Ashanti, 2016). The mean monthly temperature of the area for the 2016 cropping season ranged between $22.4{ }^{\circ} \mathrm{C}$ to $29.4{ }^{\circ} \mathrm{C}$ with the highest daily of $30.1{ }^{\circ} \mathrm{C}$ occurring in June. The mean monthly relative humidity ranged from 71 to 96 $\%$ with the peak occurring between June and September. The soil at the experimental site has been categorized as Chronic Luvisol and locally as the Bediesi series with a $\mathrm{pH}$ range of 4.0 - 6.5 suitable for root, cereal, vegetable and legume crops production legend (Asiamah et al., 2000).

2.2 Experimental design and treatments 
The field was laid in a randomized complete block design (RCBD). There were nine (9) treatments with three replications. The nine treatments were made up of eight organic manure and fertilizer rates and the control (without amendment) and chemical insecticide (Cypermetrine) and neem leaf extract were assigned to each block. The treatments were: poultry manure $\left(20 \mathrm{t} \mathrm{ha}^{-1}\right)+$ Cypermetrine (30 $\left.1 \mathrm{ha}^{-1}\right)$, cow dung $\left(20 \mathrm{t} \mathrm{ha}^{-1}\right)+$ Cypermetrine $\left(30 \mathrm{lha}^{-1}\right)$, N.P.K $(15: 15: 15)(300 \mathrm{~kg})+$ Cypermetrine $\left(301 \mathrm{ha}^{-1}\right)$, foliar + Cypermetrine $\left(30 \mathrm{lha}^{-1}\right)$, poultry manure $\left(20\right.$ tha $\left.^{-1}\right)+$ neem leaf extract, cow dung $\left(20 \mathrm{t} \mathrm{ha}^{-1}\right)+$ neem leaf extract, N.P.K $(300 \mathrm{~kg})+$ neem leaf extract, foliar + neem leaf extract and the control (no fertilizer and no insecticide).

\subsection{Soil and manure application}

Land clearing was by slashing and removing of stumps and this was immediately followed by lining and pegging. The experimental area was demarcated into plots and before transplanting, soil, poultry manure and cow dung were mixed thoroughly. Samples of no - manure soil (control) and organic manure (poultry manure and cow dung) was randomly taken prior to inorganic fertilizer application at a uniform depth of $0-20 \mathrm{~cm}$ for chemical analysis. Soil and organic manure samples analysis were carried out at the Soil Research Institute of CSIR laboratory in Kumasi, Ghana. The characteristics analyzed for included $\mathrm{pH}$ in (1:1 soil: distilled water ratio) and measured by the potentiometric method on a $\mathrm{pH}$ meter manufactured by VebPracitron in Dresden, Germany. Organic matter was determined by the Walkey and Black methodand total nitrogen was determined by the micro Kjeldahl method. Exchangeable cations were determined by flame emission photometry. Extraction was carried out by filtration or centrifugation. $\mathrm{Ca}$ and $\mathrm{Mg}$ were determined using an atomic absorption or spectrometry (AAS) after the removal of ammonium acetate and organic matter at $\mathrm{pH}$ 7.0. The result on nutrient level of organic manure and soil chemical properties are shown in Tables 1 and 2.

\subsection{Soil and manure chemical analysis}

Samples of soil, organic manure and a mixture of soil and manure from the various replicates and treatments with the exception of DI'GROW (Foliar fertilizer) plot were taken for analysis at the Soil Research Institute, Kwadaso in Kumasi. The characteristics analyzed for included; soil $\mathrm{pH}$, organic matter, organic carbon, total nitrogen, exchangeable calcium, magnesium, potassium and sodium, effective cation exchange capacity, total exchangeable bases and available phosphorus and potassium.

\subsection{Land preparation, fertilization and planting}

The land was cleared by slashing and removal of stumps, ploughed and harrowed and then lined and pegged for ISSN: 2456-1878 (Int. J. Environ. Agric. Biotech.)

https://dx.doi.org/10.22161/ijeab.66.19 planting. Cow dung and the poultry manure were applied depending upon the treatment at the rate of $20 \mathrm{t} \mathrm{ha}^{-1}$ and worked into the soil two weeks before transplanting of cabbage seedlings. The inorganic fertilizer (N.P.K15:15:15) at the rate of $300 \mathrm{~kg} \mathrm{ha}^{-1}$ was applied to the designated plots on the various replicates two weeks after transplanting. The cabbage variety used for the study was Oxylus. The seedlings were transplanted four weeks after nursing at a spacing of $50 \mathrm{~cm} \times 30 \mathrm{~cm}$ and at a depth of $1.0 \mathrm{~cm}$. Transplanting of seedlings for each season was done early in the morning. Each experimental plot contained four (4) rows and ten (10) plants within each row. There were sixteen (16) plants within the harvest area (two central rows per plot).Each experimental plot measured $2.0 \mathrm{~m} \times 3.0 \mathrm{~m}$ with $1.0 \mathrm{~m}$ between plots and 2.0 $\mathrm{m}$ between blocks. The total field size for each cropping season was $27.0 \mathrm{~m}$ x13.0 $\mathrm{m}\left(358.8 \mathrm{~m}^{2}\right)$.

\subsection{Data collection and analysis}

The vegetative data collected were percentage plant establishment and number of open leaves. The percentage plant establishment was measured at 21 days after planting (DAT).This was achieved by counting the number of plants in the two middle rows per plot and the percentage crop establishment estimated. The number of open leaves was counted from the two middle rows per plot at two weeks interval from 21 DAT to 63 DAT. Days to head initiation, head weight per plant and head diameter were estimated from the two central rows. Days to head initiation was counted from transplanting date to first harvest day when heads were firm. Head diameter was measured from the middle portion of the head using the vernier caliper. Cabbage head from the two middle rows per plant at harvest were weighed for the determination of head weight $(\mathrm{kg})$ per plant using electronic weighing scale. Harvest index was estimated by dividing the fresh weight of head by the above ground fresh biomass of the plant. The data collected were analyzed using Analysis of Variance (ANOVA).The data obtained were analyzed using GenStat Release 11 statistical package and the Least Significant Difference (LSD) was used to separate the means at $5 \%$ level of probability.

\section{RESULTS AND DISCUSSION}

\subsection{Nutrient levels of organic amendments}

Generally, the nutrient levels of the poultry manure applied in the 2015 cropping season was comparatively higher than the cow dung (Table 1). In 2016, both organic amendments had lower nutrient level compared to that of 2015. The level of potassium was 0.1 and $0.3 \%$ for poultry manure and cow dung respectively in 2016.The $\mathrm{pH}$ 
for 2015 for both amendments was almost neutral and that of the 2016 was moderately acidic.

Table 1: Nutrient levels of organic amendments for 2015 and2016 cropping seasons

\begin{tabular}{llcccc}
\hline & Cropping seasons & $\mathrm{pH}$ & $\mathrm{Ca}(\%)$ & $\mathrm{Mg}(\%)$ & $\mathrm{P}(\%)$ \\
\hline 2015 & 6.18 & 3.40 & 1.92 & 0.63 \\
\hline 2015 & 6.87 & 1.00 & 1.05 & 0.23 \\
\hline & 2016 & 5.97 & 2.11 & 0.48 & 0.70 \\
\hline & 4.89 & 0.14 & 1.10 & 0.25 \\
\hline
\end{tabular}

3.1 Soil Chemical properties before and after treatment application for 2015 and 2016 cropping seasons

In 2015, soil analysis before application of treatments indicated that the soil was slightly acidic with a $\mathrm{pH}$ of 6.13, whereas that of 2016 was moderately acidic with a $\mathrm{pH}$ of 5.70 (Table 2). The Nitrogen, Potassium and Organic matter contents for both seasons were $\leq 0.06 \%, 0.27 \%$ and $\leq 1.16 \%$ respectively

(Table 2) (Soil analytical data guide of CSIR - SRI, 2007). Cations levels were low in the range of $0.1-4.8$ meq/100g; calcium had an average of $4.5 \mathrm{meq} / 100 \mathrm{~g}$ and the total exchangeable bases (TEB) were 6.13 and 5.45 for both cropping seasons. Effective cation exchange capacity for both cropping seasons was low, ranging between 6.00 $\mathrm{meq} / 100 \mathrm{~g}$ and $6.23 \mathrm{meq} / 100 \mathrm{~g}$ respectively (Table 2). The $\mathrm{pH}$ of the fertilized soils remained slightly acidic or neutral (6.18 - 6.87) compared to the untreated soil which remained slightly acidic (6.13) after the 2015 season (Tables 2). After the 2016 cropping season, soils of the untreated, poultry manure or N.P.K $(15: 15: 15)$ remained moderately acidic $(5.70-5.97)$ while that treated with cow dung became very acidic (Tables 2 ). The cow dung treated plots recorded higher levels of organic carbon than poultry manure, N.P.K (15:15)15), or the untreated (control) for both cropping seasons. After the 2015 cropping season, soil amendments slightly improved percentage total nitrogen, however, they still remained within the low range (Tables 2).Soil amendments improved percentage total $\mathrm{N}$ from the initial low levels to moderately high levels after the 2016 cropping season. While cow dung or poultry manure slightly improved organic matter, though still in the low category after the 2015 season, they significantly improved organic matter to the moderate or high levels after the 2016 cropping season. The application of cow dung left more organic matter in the soil in both years than the other amendments. Low levels of exchangeable cations, total exchangeable bases and effective cation exchange capacity were recorded for all treatments after Koth seasons, ${ }^{\mathrm{N}}(\%)$ though slightly higher than the untreated (6c8ntrol). A3l.5the fertilized plots recorded moderate to high desgls of ayditable $\mathrm{P}$ or available $\mathrm{K}$ after both cropping seasons (Tables 2).

$0.10 \quad 0.86$

The differences in $\mathrm{pH}$ and nutrient levels of the organic manure in 28.75 and 2016 could be due to differences in organic matter. It has been suggested that the growth of plants is optimal when soil $\mathrm{pH}$ is between 5.8 and 6.5 and sometimes to a maximum of 7.5 depending on the plant species (Ontario Ministry of Agriculture, 2009). The application of the poultry manure and cow dung allowed the soil $\mathrm{pH}$ fall within a range needed for maximum plant growth except for cow dung in 2016. The $\mathrm{pH}$ of the soil became acidic after the season because $\mathrm{pH}$ of the cow dung was acidic. This could be that the parent material for soil formation has a role to play in the overall $\mathrm{pH}$ of the soil formed. It has been established that soils respond differently to changes in $\mathrm{pH}$ depending on the soil's buffering ability (CEC) (Page-Dumroese et al. 2006). The initial CEC of the soil in 2016 before the application of the cow dung was low and this does not allow the holding of cations to the soil surfaces to aid in neutralization. Such soils are unable to control nutrient losses through leaching too.

The application of organic manure provides benefits of improved fertility, water holding capacity, structure, increased organic matter and organic carbon (Adebayo et al. 2011). Much organic matter and carbon was left on the cow dung treated plots principally because cow dung needs much time to decompose than poultry manure and therefore has a longer residual effect than poultry manure. Cow dung may have a longer stay to decomposition than poultry, hence the result. According to Zaman (2017), cow dung has been documented long as perhaps the best desired animal manures due to its high nutrient and organic matter content. The application of cow dung raises the organic carbon of degraded soils which may result in improving activity of beneficial soil microorganisms and the fertility of the soil by increasing availability of nutrients for plants from soil. 


\begin{tabular}{|c|c|c|c|c|c|c|c|c|c|c|c|}
\hline Treatment & Year & $\begin{array}{l}\mathrm{pH} \\
1: 1\end{array}$ & $\begin{array}{c}\text { Org } \\
\text { C } \\
(\%)\end{array}$ & $\begin{array}{l}\text { Tota } \\
1 \mathrm{~N} \\
(\%)\end{array}$ & $\begin{array}{c}\text { Org } \\
\text { Matt } \\
\text { er } \\
(\%)\end{array}$ & Exchangeable Cations (meq/100g) & TEB & $\begin{array}{l}\text { ECEC } \\
(\mathrm{meq} / 100 \\
\mathrm{g})\end{array}$ & $\begin{array}{c}\text { Base } \\
\text { Sat } \\
(\%)\end{array}$ & $\begin{array}{l}\text { Avai } \\
1 \mathrm{P} \\
(\mathrm{pp} \\
\mathrm{m})\end{array}$ & $\begin{array}{c}\text { Avail } \\
\mathrm{K}( \\
\mathrm{ppm})\end{array}$ \\
\hline
\end{tabular}

$\mathrm{Ca}^{2+} \quad \mathrm{Mg}^{2+} \quad \mathrm{K}^{+} \quad \mathrm{Na}^{+}$

\begin{tabular}{|c|c|c|c|c|c|c|c|c|c|c|c|c|c|c|}
\hline \multicolumn{15}{|c|}{ Initial soil properties } \\
\hline $\begin{array}{l}\text { Cropping } \\
\text { season }\end{array}$ & 2015 & 6.13 & 0.64 & 0.05 & 1.10 & 4.81 & 1.07 & 0.25 & 0.10 & 6.13 & 6.23 & 98.39 & $\begin{array}{c}24.3 \\
2\end{array}$ & 47.99 \\
\hline $\begin{array}{l}\text { Cropping } \\
\text { season }\end{array}$ & 2016 & 5.70 & 0.67 & 0.06 & 1.16 & 4.27 & 0.80 & 0.27 & 0.11 & 5.45 & 6.00 & 90.83 & 7.64 & 11.00 \\
\hline \multicolumn{15}{|c|}{ Soil properties after soil amendment } \\
\hline Cow dung & 2015 & 6.87 & 0.67 & 0.07 & 1.16 & 5.87 & 0.53 & 0.69 & 0.24 & 7.09 & 7.19 & 98.61 & $\begin{array}{l}27.1 \\
1\end{array}$ & 168.51 \\
\hline $\begin{array}{l}\text { Poultry } \\
\text { manure }\end{array}$ & 2015 & 6.18 & 0.33 & 0.08 & 1.15 & 5.34 & 0.53 & 0.38 & 0.16 & 0.25 & 6.35 & 98.43 & $\begin{array}{l}49.4 \\
3\end{array}$ & 79.39 \\
\hline N.P.K & 2015 & 6.29 & 0.30 & 0.06 & 1.02 & 5.34 & 0.27 & 0.27 & 0.13 & 5.88 & 5.98 & 98.33 & $\begin{array}{l}33.5 \\
6\end{array}$ & 51.96 \\
\hline Untreated soil & 2015 & 6.13 & 0.64 & 0.05 & 1.10 & 4.81 & 0.25 & 0.25 & 0.10 & 6.13 & 6.23 & 98.39 & $\begin{array}{l}24.3 \\
2\end{array}$ & 47.99 \\
\hline Cow dung & 2016 & 4.89 & 1.99 & 0.18 & 3.44 & 2.94 & 0.52 & 0.72 & 0.25 & 4.43 & 5.63 & 78.69 & $\begin{array}{l}10.8 \\
4\end{array}$ & 168.51 \\
\hline $\begin{array}{l}\text { Poultry } \\
\text { manure }\end{array}$ & 2016 & 5.97 & 0.86 & 0.17 & 2.78 & 5.07 & 0.93 & 0.24 & 0.16 & 6.56 & 6.86 & 95.63 & $\begin{array}{l}19.2 \\
1\end{array}$ & 79.39 \\
\hline N.P.K & 2016 & 5.87 & 1.61 & 0.14 & 1.48 & 3.34 & 0.67 & 0.28 & 0.15 & 4.44 & 4.84 & $91 . .74$ & $\begin{array}{l}10.3 \\
4\end{array}$ & 51.96 \\
\hline Untreated soil & 2016 & 5.70 & 0.67 & 0.06 & 1.16 & 4.27 & 0.80 & 0.27 & 0.11 & 5.45 & 6.00 & 90.83 & 7.64 & 11.00 \\
\hline
\end{tabular}

3.2 Effect of soil amendment on vegetative growth performance

The percentage crop establishment was not significantly affected by any of the fertilizers combined with insecticides and was similar to the control in 2015 (Tables 3). Generally, higher percentage crop establishment ( $>95$ $\%)$ was achieved across treatments with NPK + Cypermetrine, Poultry manure + neem, N.P.K (15:15:15) + Neem or Foliar fertilizer + neem achieving $100 \%$ crop establishment. Similarly, in 2016, fertilizer application combined with insect control did not negatively affect crop establishment. The percentage established crop population ranged between 96 and 100 (Table 3). Generally, number of open leaves was not significantly affected by fertilizer and insecticide combinations from 21 DAT to 63 DAT in 2015 (Table 5). All the treatment effect increased between 21 and 35 DAT in number of open leaves, after which some begun declining. The number of open leaves increased from 21DAT to $35 \mathrm{DAT}$, peaked at 49DAT and then declined at 63 DAT in 2016 (Table 3). There were no significant differences between treatments in number of open leaves at 21DAT. However, at 35 and 45 DAT, cabbage treated withcow dung combined with Cypermetrine or neem produced significantly more open leaves than the control or foliar fertilizer combined with Cypermetrine (Table 3).

The high percentage crop stand establishment achieved with the application of the treatments is very important to cabbage production since crop stand at harvest is a very important determinant of yield at the end of the cropping season. A look at the number of open leaves dynamics is an indication that head initiation started from the point when the number of open leaves decline. Number of open leaves started declining at 49 DAT for the control which was 2 weeks later than for Poultry manure, cow dung or NPK (15:15:15) combined with any of the insecticides and was confirmed by data on days to head initiation. It is clear that plant nutrients play a major role in whether head initiation would happen at the right time or it would be 
delayed. According to the report of Radiovich et al., (2005), cabbage head development is quick and efficient when adequate nutrients are supplied to the plants and there are enough functional outer leaves for photosynthesis with $\mathrm{N}$ being the most needed nutrient.

According to the report of John et al., (2004), poultry manure contained essential nutrient elements associated with photosynthetic activities and thus promote roots and vegetative growth. Roy and Kashem (2014) also reported that cow dung resulted in significant increase in soil nitrogen and other soil properties necessary for crop yield and productivity. According to the report of Roy and Kashem (2014), adequate amounts of nitrogen may be obtained from reasonable amounts of organic matter

Table 3: Effect of Treatments on Percentage Crop Establishment (\%), and number of open leaves, (2015)

\begin{tabular}{|c|c|c|c|c|c|c|c|c|c|c|}
\hline \multirow[t]{3}{*}{ Treatment } & \multirow{2}{*}{\multicolumn{2}{|c|}{$\begin{array}{l}\begin{array}{l}\text { Percentage Crop } \\
\text { Establishment }(\%)\end{array} \\
\text { Cropping season }\end{array}$}} & \multicolumn{8}{|c|}{ Number of open leaves ( Days after transplanting) } \\
\hline & & & \multicolumn{4}{|c|}{ Cropping season (2015) } & \multicolumn{4}{|c|}{ Cropping season (2016) } \\
\hline & 2015 & 2016 & 21 & 35 & 49 & 63 & 21 & 35 & 49 & 63 \\
\hline PoultryMan+Cyper & 95.83 & 100.00 & 19 & 16 & 11 & 16 & 13 & 19 & 23 & 19 \\
\hline Cow dung+ Cyper & 95.83 & 100.00 & 19 & 17 & 14 & 17 & 13 & 21 & 27 & 19 \\
\hline N.P.K+ Cyper & 100.0 & 97.92 & 18 & 18 & 13 & 18 & 11 & 18 & 23 & 17 \\
\hline Foliar + Cyper & 95.83 & 97.92 & 17 & 18 & 16 & 18 & 11 & 19 & 22 & 18 \\
\hline PoultryMan+NLE & 100.0 & 95.83 & 19 & 17 & 14 & 17 & 12 & 20 & 23 & 17 \\
\hline Cow dung+ NLE & 95.83 & 100.00 & 19 & 22 & 20 & 22 & 13 & 20 & 28 & 18 \\
\hline N.P.K+ NLE & 100.0 & 100.00 & 18 & 21 & 20 & 21 & 13 & 22 & 27 & 21 \\
\hline Foliar + NLE & 100.0 & 100.00 & 14 & 14 & 15 & 14 & 12 & 20 & 26 & 23 \\
\hline Control & 95.83 & 100.00 & 15 & 16 & 19 & 16 & 11 & 17 & 24 & 23 \\
\hline $\operatorname{SED}(0.05)$ & 2.06 & 1.78 & 1.28 & 2.10 & 2.20 & 4.15 & 2.55 & 2.05 & 3.12 & 2.55 \\
\hline
\end{tabular}

cyper = cypermetrine, man = manure

\subsection{Effect of soil amendment on yield components}

The days to head initiation was significantly influenced by fertilizer and insecticide treatments in the 2015 experiment (Table 4). Head initiation for all treatments started $2-3$ weeks earlier than the control with poultry manure combined with neem or Cypermetrine producing the least days to head initiation. In 2016, days to cabbage head initiation ranged between 78 -97 days (Table 4). However, the production of cabbage without any form of fertilizer and insecticide application increased the number of days to head initiation by 10 to 19 days. The use of Poultry manure combined with neem or Cypermetrine required significantly less days (6-8days) to head initiation compared with NPK combined with Neem or applied to the soil and is directly responsible for vegetative growth of plants. Nitrogen functions in plants by being part of chlorophyll which is important in photosynthesis, and improves the quality of leaf (Roy and Kashem, 2014). According to the report of Patrick et al. (2012), yield of cabbage increased with increasing levels of nitrogen up to $390 \mathrm{~kg} / \mathrm{ha}$. Casely et al. (2006) observed that increasing rate of nitrogen (150-250 kg/ha) with basal $\mathrm{P}$ and $\mathrm{K}$ application increased yield of cabbage. The increase in water holding capacity in poultry manure and cow dung treatments also provided additional advantage for growth and yield to cabbage grown on such plots (Frempong et al.2006; Agyarko et al.2006; Ewulo, 2005). 
control, foliar fertilizer combined with neem or Cypermetrine, N.P.K combined with Cypermetrine, or cow dung combined with neem produced significantly lighter cabbage heads per plant compared with poultry manure combined with neem or Cypermetrine, cow dung combined with Cypermetrine, or N.P.K combined with neem (Table 4 ). The use of Poultry manure combined with neem or Cypermetrine produced cabbage heads per plant that were $350-450 \%$ heavier than the cabbage heads of the control $(0.20 \mathrm{~kg})$. N.P.K combined with neem or Cypermetrine also produced heads that were $150-315 \%$ heavier than the control (Table 4).

Cabbage yield (tonnes per hectare) was significantly influenced by fertilizer and insecticide treatment in 2015 (Table 4). The application of poultry manure and Cypermetrine or neem significantly produced 32.50 -
37.23 tonnes $(468-537 \%)$ more cabbage than the control. Foliar fertilizer regardless of the insecticide combined produced yields similar to the control (Table 4). In 2016, significantly higher yields of 278, 266, 289 and $131 \%$ over the control ( 9 tonnes/ha) were recorded for poultry manure combined with neem, N.P.K (15:15:15) combined with neem, poultry manure combined with Cypermetrine, or cow dung combined with neem respectively over the control (Table 4). The control or foliar combined with Cypermetrine recorded least yields of 10 and 9 tonnes/ha respectively (Table 4). Harvest index was however, not influenced by the treatments (Tables 4 ). Poultry manure combined with neem leaf extract and N.P.K (15:15:15) combined with neem leaf extract had similar harvest index in 2016 (Table 4).

Table 4: Effect of fertilizer + insecticides on cabbage yield and yield components for 2015cropping season

\begin{tabular}{lllllllllll}
\hline Treatment & $\begin{array}{l}\text { Days to Head } \\
\text { Initiation }\end{array}$ & $\begin{array}{l}\text { Head } \\
\text { Diameter } \\
(\mathbf{c m})\end{array}$ & $\begin{array}{l}\text { Head } \\
(\mathbf{k g})\end{array}$ & Weight & Yield (ton/ha) & Harvest Index \\
& $\mathbf{2 0 1 5}$ & $\mathbf{2 0 1 6}$ & $\mathbf{2 0 1 5}$ & $\mathbf{2 0 1 6}$ & $\mathbf{2 0 1 5}$ & $\mathbf{2 0 1 6}$ & $\mathbf{2 0 1 5}$ & $\mathbf{2 0 1 6}$ & $\mathbf{2 0 1 5}$ & $\mathbf{2 0 1 6}$ \\
\hline Poultry Man+Cyper & 80.00 & 79.00 & 10.03 & 10.03 & 1.03 & 1.10 & 39.44 & 32.56 & 0.83 & 0.79 \\
\hline Cow dung+ Cyper & 82.00 & 82.00 & 10.00 & 10.00 & 0.80 & 0.73 & 24.58 & 19.11 & 0.85 & 0.82 \\
\hline N.P.K+ Cyper & 86.00 & 85.00 & 8.67 & 8.67 & 0.53 & 0.50 & 22.78 & 18.11 & 0.79 & 0.75 \\
\hline Foliar+ Cyper & 82.00 & 82.00 & 5.07 & 5.07 & 0.17 & 0.17 & 9.86 & 10.00 & 0.67 & 0.77 \\
\hline Poultry Man+NLE & 78.00 & 78.00 & 9.67 & 9.65 & 0.73 & 0.90 & 44.17 & 33.56 & 0.86 & 0.86 \\
\hline Cow dung+ NLE & 85.00 & 85.00 & 9.67 & 9.67 & 0.73 & 0.50 & 23.33 & 20.56 & 0.75 & 0.79 \\
\hline N.P.K+ NLE & 87.00 & 85.00 & 8.33 & 8.33 & 0.53 & 0.83 & 26.81 & 34.56 & 0.89 & 0.86 \\
\hline Foliar + NLE & 87.00 & 87.00 & 5.33 & 5.34 & 0.20 & 0.40 & 18.47 & 17.10 & 0.54 & 0.83 \\
\hline Control & 101.00 & 97.00 & 2.67 & 2.66 & 0.20 & 0.20 & 6.94 & 8.89 & 0.50 & 0.81 \\
\hline SED (0.05) & 4.04 & 4.17 & 2.96 & 2.94 & 0.24 & 0.28 & 10.83 & 6.81 & 0.18 & 0.16 \\
\hline
\end{tabular}

The head weight and yield of cabbage treated to poultry manure, cow dung or NPK combined with Cypermetrine or neem are indicative of the fact that nutrient supply was better on with those treatments than the foliar application. It also raises the question whether nutrient absorption for plant use may be effectively done by the roots than the leaves. Fageria et al., (2009) confirmed that while soil uptake is more common and most effective, especially when nutrients are required in higher amounts and that in such situations foliar supply alone may not be enough to supply the needed amount. The control or foliar combined with Cypermetrine recording least yields of 10 and 9 tonnes/ha respectively could be that the foliar application of fertilizer had no effect on the yield of cabbage. This disagrees with Narayan et al., (2016) who reported of maximum seed yield of cabbage $(10.37 \mathrm{q} / \mathrm{h})$ with the foliar application of $\mathrm{NP}_{2} \mathrm{O}_{5} \mathrm{~K}_{2} \mathrm{O}$ (15-15-30) against the minimum seed yield $(5.50 \mathrm{q} / \mathrm{h})$ in untreated plots. The authors further attested that the spraying of Water Soluble Fertilizers (WSF) leads to proper development of flower buds and seed setting of cabbage which ultimately improves the seed yield. However, this did not reflect in this study.

\section{CONCLUSION}

Soil amendments both organic and inorganic fertilizers remarkably improved the soil physical and chemical properties. High percentage crop establishment (>95\%) was achieved across treatments with NPK + Cypermetrine, Poultry manure + neem, N.P.K $(15: 15: 15)+$ Neem or 
Foliar fertilizer + neem achieving $100 \%$ crop establishment. The number of open leaves increased from 21DAT to 35 DAT, peaked at 49 DAT and then declined at 63 DAT. However, application of Cow dung+ NLE produced the highest number of open leaves in both seasons. Application of poultry manure and N.P.K combined with Cypermetrine significantly improved head weight and cabbage yield.

\section{ACKNOWLEDGEMENT}

The authors are grateful to the management of the Akenten Appiah-Menka University of Skills Training and Entrepreneurial Development (AAM- USTED), College of Agriculture Education, Mampong-Ashanti and Soil Research Institute of CSIR in Kumasi for the provision of land, poultry manure and cow dung from the poultry section and large ruminant section respectively of the animal farm and for the analysis of the soil and manure samples for this research work. Authors also wish to acknowledge Mr. Clement Gyeabour Kyere (Project Work Coordinator) of the Seventh-day Adventist College of Education Agona-Ashanti for his support and technical advice which contributed to the success of this manuscript.

\section{DECLARATION OF INTEREST}

The authors declare that they have no competing interests.

\section{REFERENCES}

[1] Adeniji, O. T., Tanyongana, R. and Aloyce, A. (2010). Evaluation of head yield and participatory selection of horticultural characters in cabbage (Brassica oleraceae var capitata L.). Journal of Plant Breeding and Crop Science, 2 (8), $243-250$

[2] Adebayo, A. G., Akintoye, H., A., Olufolaji, A. O., Aina, O. O., Olatunji, M. T., Shokalu, A. O. (2011). Assessment of organic amendments on vegetative development and nutrient uptake of Moringaoleifera Lam in the Nursery. Asian $J$ Plant Sci., 10:74-79.

[3] Agyarko, K., Kwakye, P.K., Bonsu, B.A., Asare - Donkor, $\mathrm{N}$ and Amanor, E. (2006). Agronomic evaluation of cattle manure for cabbage production: animal gender and physiological conditions. Nepalese Journal of Agricultural Science, 9: $76-89$.

[4] Appiah, D. O., Osman, B., and Boafo, J. (2014). Land use and misuse. Human appropriation of land eco system services in Ghana. International Journal Ecosystems, 4 (1), 24-33.

[5] Asiamah, R. D., Adjei- Gyapong, T., Yeboah, E., Fening, J. O., Amponsah, E. O. and Gaisie, E. (2000). Soil characterization and evaluation of four primary cassava multiplication sites (Mampong, Wenchi, Asuansi and Kpeve) in Ghana. SRI Technical Report No.200, Kumasi.
[6] Casely, K. D., Bicudo, J. R., Schmidt, D. R., Singh, A., Gay, S. W., Gates, R. S., Jacobsen, L. D. and Hoff, S. J. (2006). Air quality and emissions from livestock and poultry production/ waste management systems, in: Rice, J.M., Caldwell, D.F. and Humenik, F.J. (Eds).

[7] Ewulo, B. S. (2005). Effect of poultry manure and cattle manure on sandy clay loam soil. Journal of Animal and Veterinary Sciences, 4:839-841.

[8] Fageria, N. K., Filho, M. B., Moreira, A., \&Guimarães, C. M. (2009). Foliar fertilization of crop plants. Journal of plant nutrition, 32(6), 1044-1064.

[9] Frempong, M. E., Ofosu- Anim, J. and Blay, E. T. (2006). Nutrient supply strategies on growth and yield in okro (Abelmoschusesculentus. L) Moench. Journal of Horticulture, 5:73-81.

[10] Ghana Meteorological Agency - Mampong - Ashanti (2015)

[11] Ghana Meteorological Agency - Mampong - Ashanti (2016)

[12] Gudugi, I. A. S (2013). Effect of cow dung and variety on the growth and yield of okra (Abelmoschus esculentus L). Eur.J. Exp. Biol., 3:495- 498.

[13] Hassan, A., Timerman, Y., Hamdan, R., Sela, N., Avetisyan, A., Hatachmi, N., Salzberg, N. (2018). An RNAi Screen identifies New Genes Required for Normal Morphogenesis of Larval Chordotonal Organs. G3 (Bethseda), 8(6): 18711884.

[14] Hassan, M. R. and Solaiman, A. H. M. (2012). Efficacy of organic fertilizer on growth of Brassica oleraceae var capitata L. (Cabbage). International Journal of Agriculture and Crop Sciences, 4 (3), 128 - 138.

[15] John, L. W., Jamer, D. B., Samuel, L. T. and Warner, L. W. (2004). Soil fertility and fertilizers. An introduction to Nutrient Management, Pearson Education, India pp: $106-$ 153. Journal of Plant Nutrition, 31 (10): 1832 - 1843.

[16] Meena, M. L., Ram, R. B., Lata, R. and Sharma, S. R. (2010). Determining yield components in cabbage (Brassica oleraceae var capitata L.) through correlation and path analysis. International Journal of Science and Nature, 1(1): $27-30$.

[17] Milas A. S and Vincent, R. K (2017). Monitoring Landside vegetation indices for different crop treatment and soil.

[18] Narayan, S., Ahmed, N., Mufti, S., Chattoo, M., Singh, P. and Khan, F. (2016). Response of Golden Acre Cabbage to Foliar Application of Water Soluble Fertilizers on plant growth and seed yield. IRA-International Journal of Applied Sciences, 4(2):226-229.

[19] Ontario Ministry of Agriculture, Food and Rural Affairs (OMAFRA) (2009). Agronomy Guide for Field Crops. Publication 811- Queens Printer for Ontario, Toronto.

[20] Page-Dumroese, D., Jurgensen, M., Tiarks, A., Sanchez, F., Fleming, R., Krangbetter, M., Power, R., Ponder, F., Stone, D., Elioff, J. and Scott, A. (2006). Soil physical property changes on the North American Long Term Soil Productivity (LTSP) study sites: 1 and 5 years after treatment. Can. J. for Res., 36:551 - 564.

[21] Pahlar, I., Tagwira, F., Muzemu, S., Chitamba, J. (2013). Effects of soil type and manure level on the establishment 
and growth of Moringaoleifera. Int. Jour. Agric. and Forestry,

[22] Patrick, A., Lesaca A, Anabella P.T (2012). Increasing Cabbage Yield through SSNM. Bar Digest research and development

[23] Pavla, B. and Pokluda, R. (2008). Influence of Alternative Organic Fertilizers on the Antioxidant Capacity in Head Cabbage and Cucumber. Notuale Botanicae Horti Agrobotanici Cluj, 36(1) 63 - 67. PhD Thesis, Ahmadu Bello University, Zaira, p. 330.

[24] Radiovich, T. J. K., Kleinhene, M. D. and Streetter, J. G. (2005). Irrigation timing relative to head development influences yield components, sugar levels and glucosinolate concentrations in cabbage. Journal of the American Society for Horticultural Science, 130: 943- 949.

[25] Sajal, R. and Md. Abdul, K. (2014). Effects of organic manure in changes of some soil properties at different incubation periods. Open Journal of Soil Science, 4, 81-86.

[26] Shapla, A. S (2013). Effect of planting time and organic manure on growth and yield of broccoli Department of Horticulture, Sher-e-Bengla Agricultural University, Tongi, Bangladesh, MS Thesis

[27] Snr, P.A.P., Kyere, C.G., Jnr, P.A.P., Oppong, E. and Twumasi, G. (2020). Effects of Poultry Manure, N. P. K Fertilizer and Their Combination on the Growth and Yield of Sweet Pepper. Asian Journal of Agricultural and Horticultural Research, 5 (1), 14-22.

[28] Timbilla, J. A, Nyarko, K. O. (2004). A Survey of cabbage production and constraints in Ghana. Ghana Journal of Agricultural Science Vol.37 2004.93-101.

[29] Zaman, M. M. (2017). Effect of cow dung as organic manure on the growth, leaf biomass yield of Stevia rebaudiana and post-harvest soil fertility. 